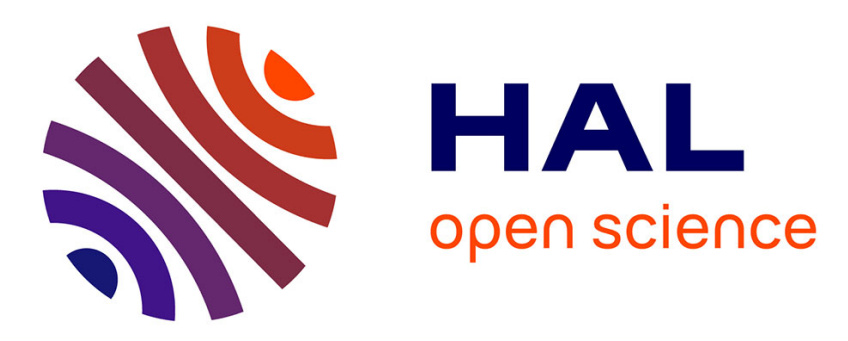

\title{
Condensation of beta-hydroxy sulfones and vinyl sulfones with aldehydes and ketones using phenyllithium as base
}

Delphine Rotulo-Sims, Laurence Grimaud, Joëlle Prunet

\section{- To cite this version:}

Delphine Rotulo-Sims, Laurence Grimaud, Joëlle Prunet. Condensation of beta-hydroxy sulfones and vinyl sulfones with aldehydes and ketones using phenyllithium as base. Comptes Rendus. Chimie, 2004, 7, pp.941. 10.1016/j.crci.2004.02.014 . hal-00087121

\section{HAL Id: hal-00087121 \\ https://hal.science/hal-00087121}

Submitted on 21 Jul 2006

HAL is a multi-disciplinary open access archive for the deposit and dissemination of scientific research documents, whether they are published or not. The documents may come from teaching and research institutions in France or abroad, or from public or private research centers.
L'archive ouverte pluridisciplinaire HAL, est destinée au dépôt et à la diffusion de documents scientifiques de niveau recherche, publiés ou non, émanant des établissements d'enseignement et de recherche français ou étrangers, des laboratoires publics ou privés. 


\title{
Condensation of $\beta$-hydroxy sulfones and vinyl sulfones with aldehydes and ketones using phenyllithium as base
}

\author{
Delphine Rotulo-Sims, ${ }^{\mathrm{a}}$ Laurence Grimaud, ${ }^{\mathrm{b}}$ [ Joëlle Prunet ${ }^{\mathrm{a}}{ }^{\mathrm{C}}$ \\ ${ }^{a}$ Laboratoire de Synthèse Organique associé au CNRS, UMR 7652, DCSO, Ecole Polytechnique, F-91128 Palaiseau, France \\ ${ }^{b}$ Laboratoire Chimie et Procédés, Ecole Nationale Supérieure des Techniques Avancées, 32 boulevard Victor, F-75015 Paris,
} France

[ Corresponding authors.

E-mail address: joelle.prunet@polytechnique.fr (J. Prunet).

E-mail address: grimaud@ensta.fr (L. Grimaud).

\begin{abstract}
Condensation of $\beta$-hydroxysulfones 7a-b with aldehydes and ketones were performed with diverse bases. Phenyllithium proved to be optimum, giving yields of compounds 9-12a-e ranging from 67 to $80 \%$. Condensation of vinyl sulfones 15a-c with aldehydes also worked very well with $\mathrm{PhLi}$, and the resulting adducts 16a-d were transformed into protected syn 1,3-diols flanked with an olefin at the $\alpha$ carbon by a new conjugate addition/elimination sequence. These products are models for the C21-C25 sub-unit of Dolabelides.
\end{abstract}

\section{Résumé}

Les $\beta$-hydroxysulfones 7a-b ont été condensées avec des aldéhydes ou des cétones en présence de différentes bases. La base de choix s'est révélée être le phényllithium, et les composés 9-12a-e sont obtenus avec des rendements variant entre 67 et 80\%. La condensation des sulfones vinyliques $\mathbf{1 5 a - c}$ avec des aldéhydes fonctionne aussi très bien avec le PhLi, et les adduits obtenus 16a-d sont transformés en 1,3-diols syn avec une oléfine sur le carbone en $\alpha$ par une nouvelle séquence de réactions comportant une addition conjuguée suivie d'une élimination. Ces produits constituent des modèles du fragment C21-C25 des Dolabélides.

Keywords: Dolabelides, hydroxy sulfones, phenyllithium, Julia olefination, vinyl sulfones

Mots clé : Dolabélides, hydroxysulfones, phényllithium, oléfination de Julia, sulfones vinyliques

In 1995, Yamada and coworkers isolated Dolabelides A and B, two 22-membered ring lactones, from the sea hare Dolabella auricularia (family Aplysiidae) [1]. In 1997, two similar 24-membered ring lactones, Dolabelides C and D, were also extracted from the same source [2]. These compounds were shown to 
exhibit cytotoxicity against $\mathrm{HeLaSe}_{3}$ cell lines with $\mathrm{IC}_{50}$ values of $6.3,1.3,1.9$ and $1.5 \mu \mathrm{g} / \mathrm{mL}$, respectively. Their structures were determined by HRFAB mass spectroscopy and 2D NMR, and their absolute configuration by the modified Mosher method [3]. Several groups have reported syntheses of Dolabelide fragments $[4,5,6]$.

The retrosynthesis we envisioned is illustrated in Fig. 1. Opening the macrolactone and disconnecting the C15-C16 bond furnishes two fragments of roughly equal size, C1-C15 and C16-C30. They would be coupled by a $B$-alkyl Suzuki reaction [7] between the vinyl iodide at $\mathrm{C} 15$ and a borane derived from the olefin at $\mathrm{C} 16$. The $\mathrm{C} 15-\mathrm{C} 30$ portion can be further disconnected through the C24-C25 double bond. In a previous paper, we described the synthesis of C16-C24 aldehyde 1 [4], which could be engaged in a Wittig coupling with phosphorane 2. An alternative to make the C24-C25 bond would be a Julia coupling between $\beta$-hydroxy sulfone $\mathbf{3}$ and ketone $\mathbf{4}$.

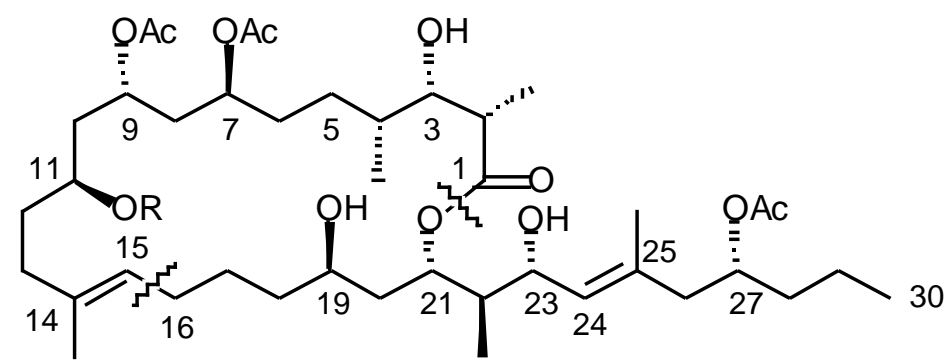

Dolabelide $A \quad R=A c$

Dolabelide B $\quad \mathrm{R}=\mathrm{H}$<smiles>C=C[C@H](O)C[C@H](O)CC[C@@H](C)[C@@H](O)C(C)C(=O)O</smiles>

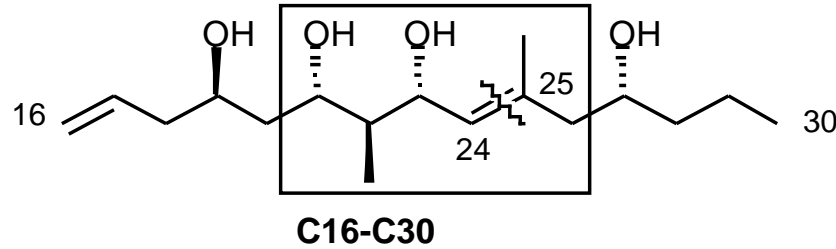

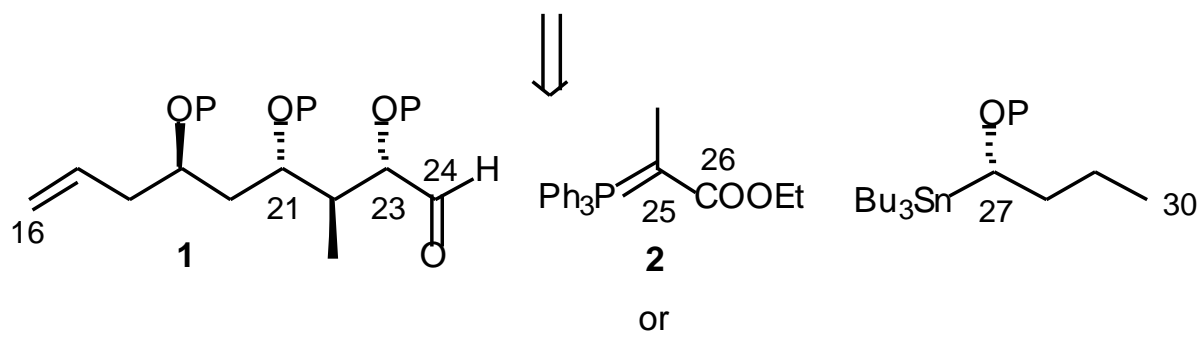

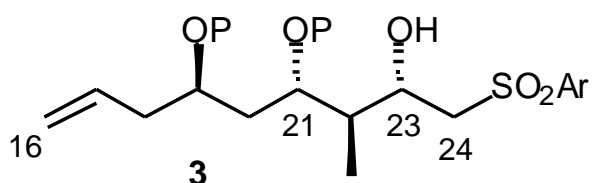<smiles>CCC[C@@H](P)CC(C)=O</smiles> 
Fig. 1. Dolabelide A retrosynthesis.

Model hydroxy sulfones 7a-b were easily prepared in two steps from vinyl sulfones $\mathbf{5}$ according to previous work in our laboratory [8]. Intramolecular conjugate addition of an intermediate hemiacetal anion made in situ from homoallylic alcohols 5a-b with benzaldehyde and potassium tert-butoxide gave the protected syn 1,3-diols 6a-b. Regioselective reduction of these benzylidene acetals with DIBAL-H furnished the corresponding hydroxy sulfones 7a-b in good yields (Fig. 2).

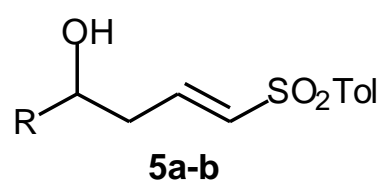

$$
\mathrm{R}=\mathrm{PHCH}_{2} \mathrm{CH}_{2}, i-\mathrm{Pr}
$$

$\mathrm{PhCHO}$, THF

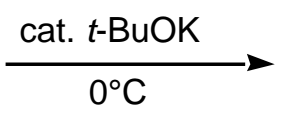

$0^{\circ} \mathrm{C}$

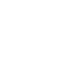

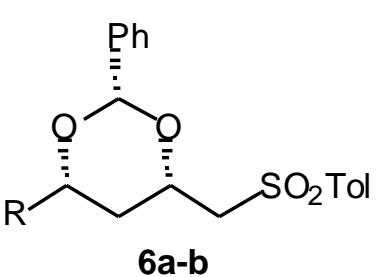

\begin{tabular}{l|l} 
DIBAL-H & \multicolumn{1}{|c}{$\mathrm{CH}_{2} \mathrm{Cl}_{2}, 20^{\circ} \mathrm{C}$}
\end{tabular}

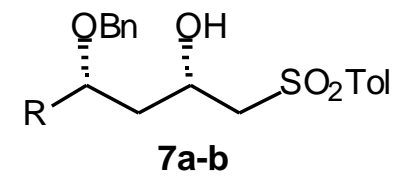

Fig. 2. Synthesis of model $\beta$-hydroxy sulfones.

First attempts of condensation of the dianions of sulfones $\mathbf{7 a}$ and $\mathbf{7 b}$ according to a literature procedure [9,10] gave modest yields of the desired diols 8 (from 23 to $37 \%$ when using isobutyraldehyde, and 59\% for benzaldehyde) due to the poor conversion of the starting sulfones (Fig. 3) [8]. Several additives were employed to try to improve the conversion of sulfones 7a-b: $\mathrm{LiBr}, \mathrm{HMPA}$, TMSCl or AcCl, with no success. Other bases were screened: $\mathrm{BuLi} / t$-BuOK, $\mathrm{LDA}, \mathrm{Et}_{2} \mathrm{NLi}$ gave similar results, and the conversion did not exceed $12 \%$ with $i$-PrMgCl [11].

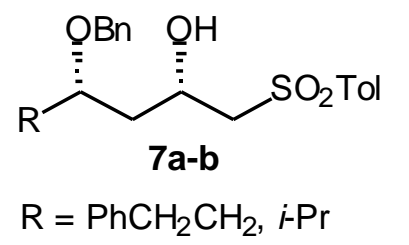

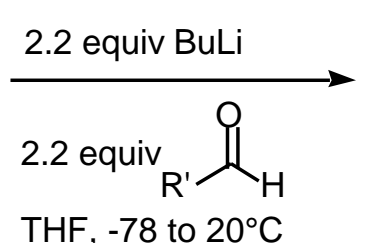

$\mathrm{R}^{\prime}=i-\mathrm{Pr}, \mathrm{Ph}$<smiles>[R]C(O)C[C@@H](O)[C@@H]([SeH])[C@H]([R5])O</smiles>

$23-59 \%$

Fig. 3. First attempts of condensation of $\beta$-hydroxy sulfones with aldehydes.

Finally, $\mathrm{PhLi} \bullet \mathrm{LiBr}$ proved to be the base of choice. This reagent was first utilized by Masamune for a Julia coupling during the final steps of the synthesis of bryostatin 7 [12]. Yields improved to 67-80\%, and 
the yields based on recovered sulfones were excellent (up to 95\%). Moreover, only 1.2 equivalent of aldehydes can be used for optimum results. The crude adducts were directly transformed into the corresponding acetonides for two purposes: easier separation of the products from the starting hydroxy sulfones, and determination of the relative stereochemistry of the newly formed centers. Four diastereomers were observed in all cases, and their configuration was proved by ${ }^{1} \mathrm{H}[9]$ and ${ }^{13} \mathrm{C}$ NMR analysis $[13,14,15]$. Tanikaga et al reported the formation of only two diastereomers for the condensation of simpler $\beta$-hydroxy sulfones with similar aldehydes [10]. They correspond to the major isomers in our case (compounds 9 and 10). We have no explanation for the discrepancy between the selectivities in our study and in Tanikaga's report.<smiles>[R]OC(O)C[C@@H](O)C[SeH]</smiles>

7a-b

$\mathrm{R}=\mathrm{PhCH}_{2} \mathrm{CH}_{2}, i-\mathrm{Pr}$

$$
\mathrm{R}^{\prime}=i-\mathrm{Pr}, \mathrm{Ph}, \mathrm{Et} \mid \begin{aligned}
& \text { 1) } 2.1 \text { equiv } \mathrm{PhLi} \mathrm{LiBr} \\
& 1.2 \text { equiv } \mathrm{R}^{\prime} \mathrm{CHO} \\
& \mathrm{THF},-78 \text { to }-40^{\circ} \mathrm{C} \\
& \text { 2) } 2,2-\text { Dimethoxypropane } \\
& \text { cat. CSA }
\end{aligned}
$$<smiles>[R]C(=[18O])C[C@H]1OC(C)(C)O[C@@H]([R])[C@H]1[Se](=O)(=O)O</smiles><smiles>[R]C(Cc1ccccc1)OC1C([R5])OC(C)(C)OC1[R5]</smiles>

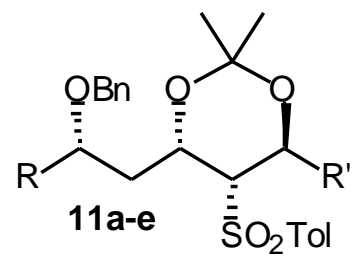<smiles>[R]C(Cc1ccccc1)[C@H]1OC(C)(C)O[C@@H]([R6])[C@@H]1[Se]O</smiles>

\begin{tabular}{cllll}
\hline $\mathrm{R}$ & $\mathrm{R}^{\prime}$ & Products & \multicolumn{1}{c}{ Yield (corr.) } & \multicolumn{1}{c}{$\mathbf{9 / 1 0 / 1 1 / 1 2}$} \\
\hline $\mathrm{PhCH}_{2} \mathrm{CH}_{2}$ & $i-\mathrm{Pr}$ & $\mathbf{9 - 1 2 a}$ & $78 \%(90 \%)$ & $65: 22: 8: 5$ \\
& $\mathrm{Et}$ & $\mathbf{9 - 1 2 b}$ & $67 \%(84 \%)$ & $64: 23: 9: 4$ \\
& $\mathrm{Ph}$ & $\mathbf{9 - 1 2 c}$ & $70 \%(83 \%)$ & $78: 9: 10: 3$ \\
$i-\operatorname{Pr}$ & $i-\mathrm{Pr}$ & $\mathbf{9 - 1 2 d}$ & $76 \%(95 \%)$ & $n d^{\mathrm{a}}$ \\
& $\mathrm{Ph}$ & $\mathbf{9 - 1 2 e}$ & $80 \%(92 \%)$ & $76: 17: 4: 3$ \\
\hline
\end{tabular}

${ }^{a}$ Not determined

Fig. 4. Condensation with PhLi as base. 
Addition of dianions of $\beta$-hydroxy sulfones to ketones have also been reported [16], so we tried the condensation of sulfone 7a with acetone (Fig.5). The yield of this reaction is not as satisfying as with aldehydes, but the selectivity is comparable.

1) 2.1 equiv $\mathrm{PhLi} \cdot \mathrm{LiBr}$<smiles>[R]C(CBr)C[C@@H](O)C[SeH]</smiles>
1.2 equiv acetone THF, -78 to $-40^{\circ} \mathrm{C}$<smiles>[R]C(Cc1ccccc1)C[C@H]1OC(C)(C)OC(C)(C)C1[Se][O-]</smiles>

2) 2,2-Dimethoxypropane cat. CSA, $20^{\circ} \mathrm{C}$ $40 \%(65 \%)$

$d r 78: 22$

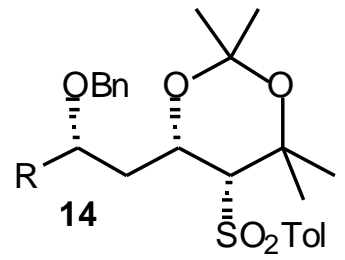

Fig. 5. Condensation of sulfone 7a with acetone.

Since we had difficulties coupling sulfones 7 with aldehydes or ketones at the beginning of this study, we examined an alternate route to model compounds of the C16-C30 portion of Dolabelides, featuring a syn 1,3-diol unit flanked by an olefin (see the boxed portion of C16-C30 in Fig. 1). We envisaged to create the C24-C25 before performing the conjugate addition which installs the syn diol functionality. Hydroxy vinyl sulfones $5\left(\mathrm{R}=\mathrm{PhCH}_{2} \mathrm{CH}_{2}, \mathrm{Ph}, \mathrm{C}_{4} \mathrm{H}_{9}\right)$ were protected as the corresponding tert-butyldimethylsilyl or triethylsilyl ethers, leading to compounds $\mathbf{1 5 a}$-c in quantitative yield (Fig. 6). Deprotonation of sulfone 15a $\left(\mathrm{R}=\mathrm{PhCH}_{2} \mathrm{CH}_{2}\right)$ was first attempted with tert-BuLi, followed by addition to isobutyraldehyde. The reaction was clean, but 16 a was obtained in only $40 \%$ yield. Here again, $\mathrm{PhLi} \cdot \mathrm{LiBr}$ solved this problem, and sulfones 16a-d were formed in good to excellent yields (64-83\%) as 1:1 mixtures of diastereomers (Fig. 6).

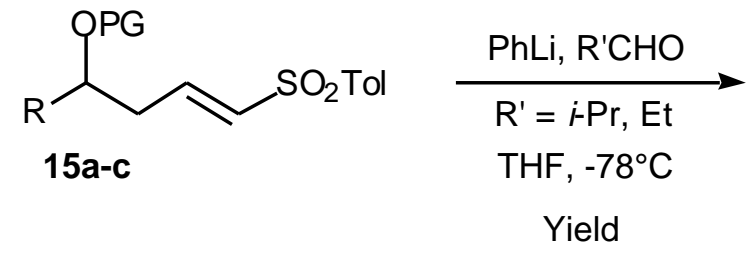

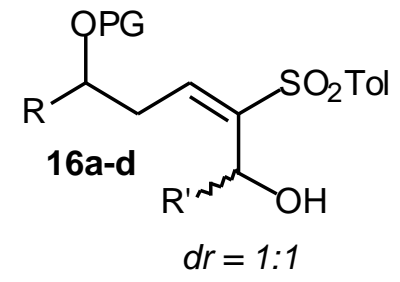

\begin{tabular}{lcclcc}
\hline \multicolumn{1}{c}{$\mathrm{R}$} & $\mathrm{PG}$ & Precursor & $\mathrm{R}^{\prime}$ & Product & Yield \\
\hline $\mathrm{PhCH}_{2} \mathrm{CH}_{2}$ & TBS & 15a & Et & $\mathbf{1 6 a}$ & $74 \%$ \\
& & & $i-\mathrm{Pr}$ & $\mathbf{1 6 b}$ & $72 \%$ \\
$\mathrm{Ph}$ & TES & $\mathbf{1 5 b}$ & $\mathrm{Et}$ & $\mathbf{1 6 c}$ & $64 \%$ \\
$\mathrm{C}_{4} \mathrm{H}_{9}$ & & $\mathbf{1 5 c}$ & $i-\mathrm{Pr}$ & $\mathbf{1 6 d}$ & $83 \%$ \\
\hline
\end{tabular}


Fig. 6. Alternate route to models of the C16-C30 portion of Dolabelides.

The reason why PhLi gives such good results with both hydroxy sulfones and vinyl sulfones is not entirely clear. It is slightly less basic than $\mathrm{BuLi}$, so deprotonation of the aromatic protons ortho to the sulfone group is less favored [17]. On the other hand, $\mathrm{PhLi}$ is less prone to monoelectronic transfers which might reduce the sulfonyl group.

In order to perform the conjugate addition on compounds $\mathbf{1 6}$, we needed to deprotect the silyl ether (PG), after having protected the alcohol group to prevent it from interfering in the 1,4-addition. At this point, we surmised it would be possible to install the syn 1,3-diol and the double bond at the same time, by activating the alcohol instead of protecting it. The anion formed from $\mathbf{1 7}$ after the conjugate addition would undergo an elimination with the neighboring activated group, leading to vinyl sulfone 18 (Fig. 7). In this case, a full equivalent of base would be necessary to drive the reaction to completion.
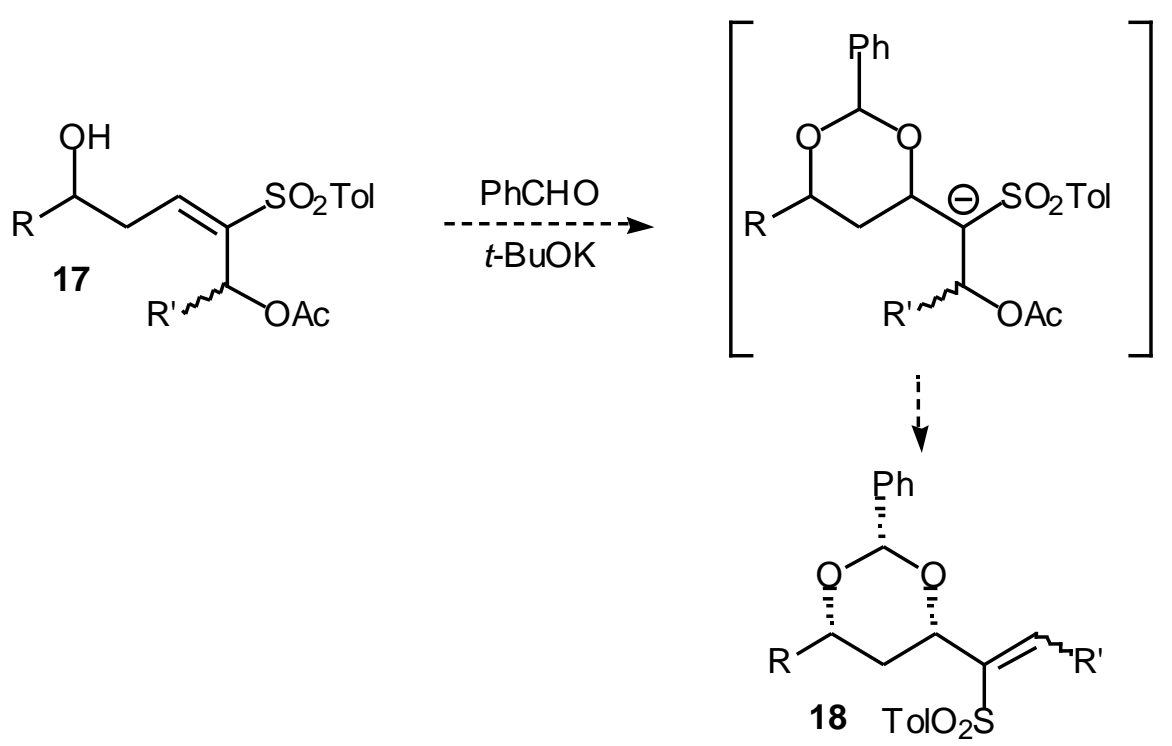

Fig. 7. Mechanism of the conjugate addition/elimination sequence.

To verify this hypothesis, we transformed the alcool function of $\mathbf{1 6 a}$ into an acetate (80\%), and deprotected the silyl ether with a 5:95 aqueous HF/acetonitrile solution (92\%). The resulting compound 17 was treated with excess benzaldehyde and a stoichiometric amount of potassium tert-butoxide. We were delighted to see that benzylidene acetal 18 was obtained in $65 \%$ yield, and with a syn/anti selectivity of 93:7 (Fig. 8). The conjugate addition is under thermodynamic control [18], leading to the protected syn 1,3-diol where all the substituents are equatorial on the benzylidene ring. The fact that we observed an excellent syn/anti selectivity in the tandem conjugate addition/elimination means that the thermodynamic equilibrium 
is reached before the subsequent irreversible elimination takes place. We are currently studying this sequence, and especially the relation between the ratio of diastereomers of $\mathbf{1 7}$ and the $E / Z$ selectivity. Efforts towards the reduction of the sulfone moiety in compounds 9-12 and $\mathbf{1 8}$ are also in progress.

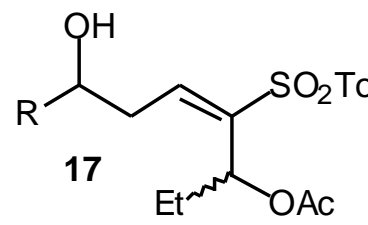

$$
d r=1: 1
$$

$\mathrm{R}=\mathrm{PhCH}_{2} \mathrm{CH}_{2}$

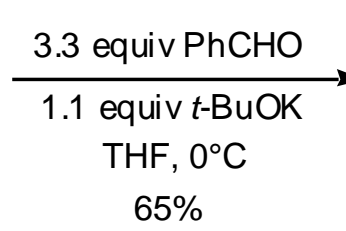

$65 \%$

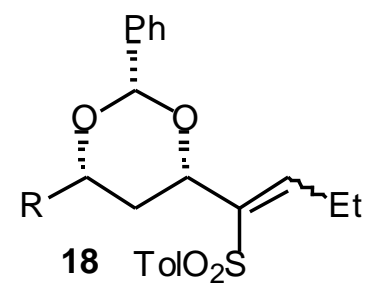

syn/anti $=93: 7, E / Z=3: 1$

Fig. 8. First attempt of conjugate addition/elimination sequence.

In summary, we have shown that $\mathrm{PhLi} \cdot \mathrm{LiBr}$ is an efficient base for the condensation of both $\beta$-hydroxysulfones and vinyl sulfones with aldehydes, and we designed a short route to syn 1,3,5-triols and to syn 1,3-diols bearing an olefin on the $\alpha$ carbon, which are model compounds for the C21-C25 sub-unit of Dolabelides.

Acknowledgments: D. R.-S. acknowledges the MENR for a fellowship. Financial support was provided by the CNRS (UMR 7652) and the Ecole Polytechnique. Pr. Jérôme Lacour is thanked for helpful discussions.

\section{References}

[1] M. Ojika, T. Nagoya, K. Yamada, Tetrahedron Lett. 36 (1995), 7491.

[2] K. Suenaga, T. Nagoya, T. Shibata, H. Kigoshi, K. Yamada, J. Nat. Prod. 60 (1997), 155.

[3] I. Ohtani, T. Kusumi, Y. Kashman, H. Kakisawa, J. Am. Chem. Soc. 113 (1991), 4092.

[4] C16-C24: L. Grimaud, R. de Mesmay, J. Prunet, Org. Lett. 4 (2002), 419

[5] C15-C24 and C25-C30: N. Desroy, R. Le Roux, P. Phansavath, L. Chiummiento, C. Bonini, J.-P. Genêt, Tetrahedron Lett. 44 (2003), 1763.

[6] C15-C30: D. R. Schmidt, P. K. Park, J. L. Leighton, Org. Lett. 5 (2003), 3535.

[7] For a recent use of such a coupling reaction, see: D. Sawada, M. Shibasaki, M. Angew. Chem. Int. Ed. 39 (2000), 209 and references therein. 
[8] L. Grimaud, D. Rotulo, R. Ros-Perez, L. Guitry-Azam, J. Prunet, Tetrahedron Lett. 43 (2002), 7477.

[9] R. Tanikaga, K. Hosoya, A. Kaji, Chem. Lett. (1987), 829.

[10] R. Tanikaga, K. Hosoya, A. Kaji, J. Chem. Soc., Perkin Trans. I (1988), 2397.

[11] A possible explanation for the poor conversion could be the enolization of the carbonyl compound, although no aldol sideproducts were observed.

[12] M. Kageyama, T. Tamura, M. H. Nantz, J. C. Roberts, P. Somfai, D. C. Whritenour, S. Masamune, J. Am. Chem. Soc. 112 (1990), 7407.

[13] S. D. Rychnovsky, D. J. Skalitzky, Tetrahedron Lett. 31 (1990), 945.

[14] D. A. Evans, D. L. Rieger, J. R. Gage, Tetrahedron Lett. 31 (1990), 7099.

[15] S. D. Rychnovsky, B. Rogers, G. Yang, J. Org. Chem. 58 (1993), 3511.

[16] K. S. Kim, J.-K. Sohng, S. B. Ha, C. S. Cheong, D. I. Jung, C. S. Hahn, Tetrahedron Lett. 29 (1988), 2847.

[17] H.-J. Gais, J. Vollhardt, Tetrahedron Lett. 29 (1988), 1529.

[18] By analogy to the conjugate addition involving unsaturated esters, see: D. A. Evans, J. A. Gauchet-Prunet, J. Org. Chem. 58 (1993), 2446. 